\title{
The Quest for Self-Actualization in Iban Motivational Novel
}

\author{
Rosemidland Anak Manggie* and Mohd Faizal Musa \\ Institut Alam dan Tamadun Melayu (ATMA) \\ Universiti Kebangsaan Malaysia \\ Corresponding author: rosemidland@gmail.com
}

\begin{abstract}
The study of modern motivational novels written in the Iban language is interesting as very limited research has been done regarding Iban Literature in general. The Ibans are well known for their oral narratives that consist of traditional prose and poetry. However, Iban writers like Harry Usup Umbar has tried a new dimension by writing and motivating readers through modern novels like Semaya Jawai. This paper aims to motivate young readers especially teenagers from poverty stricken families to go for self-actualization in their life. The methodology chosen to analyze this novel is Qualitative Content Analysis. As a framework of operation, the psychology theory of Maslow's Hierarchy of Needs is used. All the five levels of motivation namely the physiological needs, safety needs, love needs, esteem needs, and the needs for self-actualization will be used to analyze the main character's motivation level in the story and the hurdles that she experienced along the way until she is self-actualized as a person. From this research, it is found that each and every basic human needs is linked to the next tiers in the hierarchy and this contributes to the motivation level of a poor student like the character in the novel. A student's motivation level can go down if she or he is deprived of any basic needs in the hierarchy. This finding can be used to help poor rural kids who are demotivated in their studies. By understanding their basic needs and obstacles that they face in their daily life, educators can help these underprivileged pupils to achieve self-actualization.
\end{abstract}

Keywords: Harry Usup Umbar, Semaya Jawai, Content Analysis, Maslow's Hierarchy of Needs, Iban motivational novel

\section{Introduction}

According to Chemaline (2013), Sarawak consists of 23 main ethnics and many other sub ethnics. The Ibans is one of the many ethnics in Sarawak, Malaysia. Sarawak is situated in the island of Borneo and this largest state in Malaysia is sharing the international boundary with Kalimantan, Indonesia. The Ibans are well-known for their oral literature namely ensera and leka main. Ensera is basically a fictional narrative about older days' Iban warriors and beauties, comic characters like Apai Alui, and ensera jelu (animal fables) like mouse deer and tortoise (Clifford, 2001). It is told mainly for entertainment purposes. On the other hand, leka main is poetry for ritual and also for entertainment reasons. This oral tradition is passed from older generation to the younger generation by words of mouth. In the past, Iban parents normally tell ensera to their children as bedtime stories.

Although oral literature is significant for the Ibans, modern Iban literature such as short story and novel are not something new for them. The first modern Iban literature was written in 1975, and that was a short story entitled Batu Kuai written by a prominent 
Iban writer named Janang Ensiring. From there, modern Iban literature has expanded and many more young ambitious writers were born, namely Jantan Umbat, Thomas Bangit, George Garai and Harry Usup Umbar. Harry Usup Umbar has written quite a number of interesting reads and one of his remarkable works is a motivational novel entitled Semaya Jawai (1999).

Semaya Jawai is a novel about a young Iban teenager named Aretta Jawai who struggled to achieve her ambition. The main character of this novel hailed from a poor Iban family that grows paddy for a living. Being poor and penniless, she underwent one obstacle after another in her quest to achieve self-actualization. Fulfilling basic physiological needs and safety needs are a great challenge for the Iban family as they live far in the interior. Their dwelling can only be reached by longboats and it took a two hours trip from the small town of Selangau in Sibu, Sarawak to go to Aretta's longhouse. At the same time, Aretta does not receive full support from her own father to continue studying in form five and sit for Sijil Pelajaran Malaysia examination. Her father, Janting is violent and he restricts Aretta from going to school. However, Aretta is lucky to have a loving mother, caring teachers and understanding friends who support her in her quest for selfactualization.

For this research purposes, Semaya Jawai is classified as a motivational work as it has the elements of motivation and reading such work encourages the readers to achieve self-actualization. A motivational novel is like the merging of psychology and literature in a more relaxed form, in this case a novel written for teenagers to help boost their motivation. Motivation is an essential element in a novel as it sparks action, desire and needs of an individual. Ryan (2000) emphasizes that motivation can be sub-divided into intrinsic and extrinsic motivation. Intrinsic motivation refers to an individual's desire to explore and learn new experience. Meanwhile, extrinsic motivation is coming from other people. Normally, extrinsic motivation will be used when an individual failed to get his or her desire using intrinsic motivation.

All the first three tiers in Maslow's Hierarchy of Needs namely physiological needs, safety needs and love needs are significant for a teenager to proceed to the next tiers, that is the esteem need and eventually achieve self-actualization. Without a strong basis of physiological needs, safety needs and love needs, a teenager from the rural parts of Sarawak like Aretta might not be able to be self-actualized as a person in her life.

\section{Literature Review}

Modern Iban literature is not a popular choice among Iban scholars and that explains why there are a limited past studies found regarding Iban novels and contemporary short stories. The Ibans are very proud of their oral narratives as it is part of their identity. Nowadays, these oral narratives are passed down to younger generations via radio and youtube channels. Most scholars prefer studies regarding oral narratives, Iban language and cultural studies. Taking into consideration that past research regarding Iban novels is scarce, the researcher will look into the study of novels written in other languages analyzed using the same framework that is Maslow's Hierarchy of Needs.

Firstly, Maslow's psychology theory is applied in a paper published in Indonesia's Jurnal Pendidikan Bahasa dan Sastra about an Indonesian novel entitled Hujan (2016), written by Tere Liye. The study of this novel is carried out using the method of content analysis, and the approach chosen is Maslow's Hierarchy of Needs. In this paper, Chintya 
Bayu Lestari, Ninuk Lustyantie, and Siti Gomo Attas (2018) emphasized that the personality of a character in a literary work is an interesting research material. They further stressed that researchers are able to interpret the psychological state of the author by analyzing his or her literary work. This is portrayed in the study of self-actualization of the main character in the novel entitled Hujan. Here, the study of novel entitled Semaya Jawai will also use the same methodology that is content analysis along with Maslow's Hierarchy of Needs. Similarly, the study of the main character in Semaya Jawai is also the main focus of this study as she strives to achieve self-actualization. This novel is written by a teacher who has vast experience with students that are portrayed in the novel.

Meanwhile in Malaysia, the researcher came across a paper using Maslow's Hierarchy of Needs that is used to analyze novels written for teenagers. A paper written by Nurhamizah Hashim, Eizah Mat Hussain and Nur Yuhanis Mohd Nasir (2017) about novels entitled Merdekakan Cinta Ratna (2003) written by Sri Rahayu Mohd Yusop and Beraraklah Awan Pilu (2006) by Abd. Latip Talib published in PENDETA - Journal of Malay Education and Literature is focusing on the safety needs of the main character. This is related to the safety needs mentioned by Maslow in his hierarchy of needs as any individual yearns for personal safety from harm, financial stability, and free from fear. Although the paper is only focusing on the safety needs of the main characters in the novels, the way the analysis is carried out can still be implemented in the study of Semaya Jawai. This is because the safety needs is one of the significant domains in the study of the novel.

Furthermore, Akbar Yunadi, Singgih Daru Kuncara, and Nita Maya Valiantien (2020) in a published paper in Indonesia's Jurnal Bahasa, Sastra, Seni, dan Budaya also use Maslow's Hierarchy of Needs as the framework in analysing an English novel entitled Rooftoppers (2013) by Katherine Rundell. Rooftoppers is a story about Sophie who survived a shipwreck as a baby and was later adopted by a loving bachelor named Charles. Similar to the study of Semaya Jawai, the study also focuses on the psychological needs of the main character. Here, the method of descriptive qualitative research is used to analyze the needs of the main character. The research focused on dialogues, narration, and acts performed by the main character. The data are presented in words, phrases, sentences, and paragraphs. Same methodolody and framework will be applied to the study of Semaya Jawai as well.

Lastly, another paper written by Imam Ghozali (2020), published in another Indonesian journal, Pancaran Pendidikan also focuses on the fulfillment of human needs, this time in another English novel entitled Sense and Sensibility by Jane Austen (1811). This paper is about Elinor, the main character in Sense and Sensibility who struggled to fulfill her needs, from physiological needs to self-actualization. The method used to analyze the novel is qualitative descriptive and the data are in the form of words, sentences, and paragraphs that are linked to Maslow's Hierarchy of Needs. In this paper, Imam Ghozali (2020) emphasized that research in the field of literature has evolved as nowadays, there is a tendency to merge literature with other disciplines. One of the popular combination is psychology and literature, as psychology can be used to study the psychological side of human beings associated with literary works.

Taking into consideration that the merging of psychology and literature is getting popular, the researcher is trying a new dimension that is the study of an Iban novel using Maslow's Hierarchy of Needs as the framework. It is hoped that such study will 
eventually help to boost the popularity of modern Iban literature in line with the traditional oral narratives.

\section{Methodology}

This study will use the methodology of Content Analysis alongside with self-motivation theory of Maslow's Hierarchy of Needs to analyze the novel entitled Semaya Jawai (Jawai's Promise). According to Krippendorff (2018), content analysis entails a systematic reading of a body of texts, images, and symbolic matter, not necessary from an author's or user's perspective. It is a research technique for making replicable and valid inferences from texts to the contexts of their use.

Stated below is a table comprising of steps used to analyze the novel using the method of Content Analysis:

Table 1 The Application of Content Analysis in Semaya Jawai

\begin{tabular}{|c|l|}
\hline Steps. & \multicolumn{1}{|c|}{ Application of Content Analysis } \\
\hline 1 & Select texts/novels \\
\hline 2 & Develop research questions \\
\hline 3 & Define coding units/context \\
\hline 4 & Analytical constructs \\
\hline 5 & Making inferences \\
\hline 6 & Validating evidence \\
\hline
\end{tabular}

Source: Aurthor

Firstly, a few novels are read and out of these novels, an Iban novel entitled Semaya Jawai is chosen on the basis that Maslow's Hierarchy of Needs can be associated with it. From here, research questions are developed. The research questions are:

i. What is Aretta's level of motivation at the beginning of the novel?

ii. What are the obstacles that Aretta have to go through on her path to selfactualization?

iii. How does Aretta overcome the challenges that she encountered along her way to achieve self-actualization?

Next, after developing research questions, coding units or contexts are defined. These coding units are word or phrases, sentences, and paragraphs that are grouped in accordance with the tiers of needs in Maslow's Hierarchy of Needs such as physiological, safety, love, esteem, and self-actualization. Below is the Table showing all the coding units, and some examples of words or phrases selected in analyzing the text.

Table 2 The Coding Units in Analysing Semaya Jawai

\begin{tabular}{|c|l|l|l|l|}
\hline No & \multicolumn{1}{|c|}{ Coding } & \multicolumn{1}{|c|}{ Key Words } & \multicolumn{1}{|c|}{ Translation } \\
\hline 1. & Physiological & Shelter & rumah panjai & longhouse \\
& & & gegar papan & wooden floor \\
& & tiang & pillar \\
& & ruai & verandah \\
& & bilik & room \\
& & dapur & kitchen \\
& & & pangking & bedroom \\
& & & sekula & school \\
\hline
\end{tabular}


Borneo Journal of Social Sciences \& Humanities DOI: https://doi.org/10.35370/bjssh.2020.2.2-01

e-ISSN: 2682-8235

(C) 2018, UCTS Publisher.

Submitted on: 07 July $2020 \quad$ Accepted on: 25 September $2020 \quad$ Published on: 31 December 2020

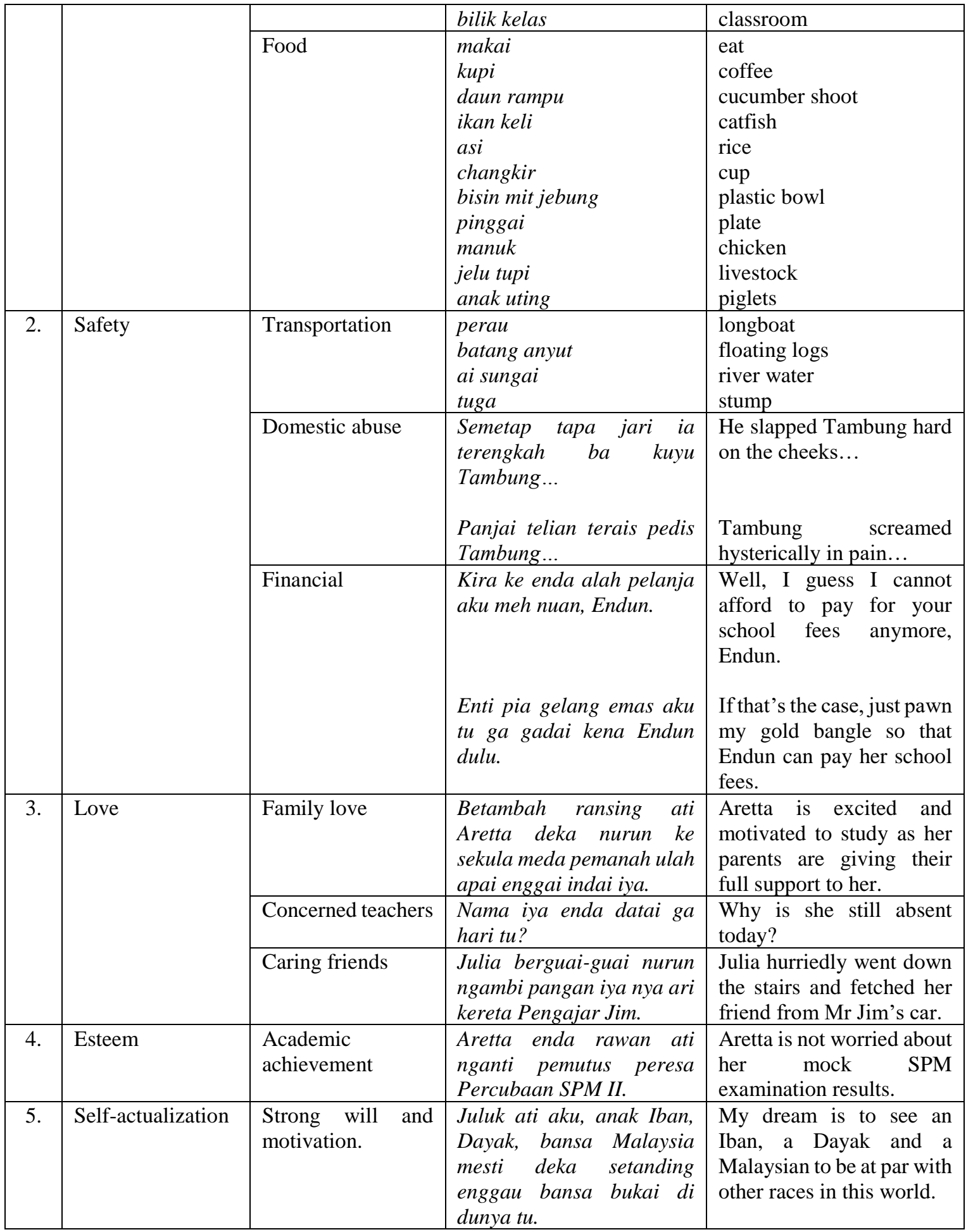

Source: Aurthor

Then, using these coding units, the plots, dialogue, characteristics, and settings are scrutinized carefully before associating them with the theory of Maslow's Hierarchy of Needs. After that, the collected data are analyzed and inferences are made. Finally, the evidence extracted from the novel is validated and findings are summarized. 
Here, the method of Content Analysis is used together with Maslow's Hierarchy of Needs to analyze the novel. According to Maslow (1954), people are motivated to fulfil basic needs before moving on to other more advanced needs. The lowest level in Maslow's Hierarchy of Needs is the physiological needs. The physiological needs are basic physical requirements such as food, water, air, clothing, and shelter. Once these basic requirements have been met, an individual is encouraged to move on to the next level of needs, which is the safety needs.

As stated by Maslow, everybody needs assurance and safety in their life. This includes the need to have protection from dangers and also security from financial aspects. Next, Maslow (1954) also stressed that as people progress up the pyramid, their needs become increasingly psychological and social. Soon, the need for belongingness and love becomes prominent. Further up the pyramid, a happy individual who has fulfilled the basic needs will go for the need for esteem and feelings of accomplishment. Lastly, at the top of the pyramid, Maslow emphasized the importance of self-actualization, which is the process of developing as a person in order to achieve a full individual potential.

While the theory is generally portrayed as a fairly rigid hierarchy, there is a degree of fixity in Maslow's Hierarchy of Needs. Maslow noted that the order in which these needs are fulfilled does not always follow this standard progression. For instance, Maslow noted that for some individuals, the need for self-esteem is more important than the need for love. For others, the need for creative fulfillment may overtake even the most basic needs.

\section{Findings and discussions}

This study will focus mainly on Aretta Jawai, the main character in an Iban novel entitled Semaya Jawai using the psychology theory of Maslow's Hierarchy of Needs. All five tiers of the hierarchy will be used to analyze the main character's level of motivation and the obstacles that she endured along her quest for self-actualization.

\section{Synopsis of the Novel Semaya Jawai}

Aretta Jawai is a 17 years old girl who hailed from an Iban longhouse in Selangau, Sibu Sarawak. The longhouse was situated quite far in the interior part of Sarawak and the only mode of transportation that can be used to reach her village is by using longboats. Aretta is a bright student and she was very keen to return to school on the first day of the school academic year to continue her form five studies. However, her father Janting was reluctant to let her continue her studies as he believed that it is pointless for girls to be highly educated. A week after school reopened, her mother Tambung took the initiative to pawn her gold bangle to a shopkeeper in Selangau so that she could send her daughter to school. Too bad, Janting was enraged when he found out that Aretta has returned to her boarding school without his permission. He pulled Aretta out of school and dragged her home. Aretta's teachers had to travel all the way from the school which was situated in Sibu to the longhouse to persuade Janting to let Aretta continue schooling. The teachers succeeded but soon Aretta was slandered to be flirting with a boy from her class. Her parents assumed that Aretta has neglected her studies as they thought that their daughter was madly in love. Janting was furious and he beat up the innocent teenage girl. As a result, he was jailed and Aretta almost dropped out of school as she faced financial constraints to continue her studies. Aretta's form teacher, Mr Jim stepped in and he 
managed to solve Aretta's financial burden. In the end, Aretta passed her Sijil Pelajaran Malaysia examination with flying colours and is on her way to pursue tertiary education in Universiti Malaysia Sarawak.

\section{A Brief Background of the Author}

Harry Usup Umbar is a retired teacher and he was born in Sibu, Sarawak on 3 June 1955. He started his teaching career in 1979 after completing training at Batu Lintang Teacher Training College, Kuching. He was posted to Sekolah Menengah Kebangsaan Luar Bandar Sibu shortly after completing his training. Later he continued his studies and managed to get a bachelor degree from Universiti Pertanian Malaysia. Harry has also taught in SMK Sungai Merah, Sibu and SMK Sibu Jaya, Sibu.

Next, Harry Usup Umbar is also an avid writer. He has won several awards in writing competitions organised by Dewan Bahasa dan Pustaka. His short story written in Malay entitled Gerila Rimba won the third place in Peraduan Menulis Novel Bulan Bahasa 1999. His other masterpiece entitled Kemelut Kasih di Persada Juang also won the second place in Peraduan Menulis Novel Remaja (2001). He was also awarded the prestigious Sarawak Literature Award 2017 in the Iban Language category.

Currently, he is the president of Sarawak Iban Writer's Association (SIWA) and Chief Editor for a local Iban magazine, Sempandai. He is a prominent figure in Sarawak in promoting the use of Iban Language. He has written textbooks for the Iban Language subject, novels, and short stories. He is also involved in writing dictionaries such as trilingual dictionary Iban-Malay-English in year 2010 and bilingual dictionary IbanMalay in 2008. He also wrote Tatabahasa Bahasa Iban in 2006. His motivational novel entitled Semaya Jawai published in 1999 is among his best literary works and aimed specifically to motivate rural Iban students in the secondary school.

Among his other interests besides story writing, is composing Iban songs. He wrote lyrics for popular local Iban singers namely Melissa Francis, Hailey Robson, Inna Mawas and David Follan to name a few. His song entitled Benang Emas sung by Hailey Robson won the best lyric in Dayak Music Awards 2016 organised by Dayak Artiste Musician Association (DAMA).

\section{The Analysis}

A strong desire or motivation to learn despite unwanted obstacles crossing in one's path of life is extremely important to determine success and subsequently achieve selfactualization. In this article, the main character of the novel who is also the subject of the study, a poor Iban student named Aretta Jawai has faced many challenges in her quest to achieve self-actualization in her life.

According to Maslow (1954), self-actualization is a desire for self-fulfilment for an individual to become actualized in what he or she has potential in. Although her physiological needs such as food, water, clothing and shelter are met, Aretta yearns for better things in her life in which she has a potential. She longs to achieve more and not simply satisfied with simple ways of living that the traditional Iban women in the longhouse are used to. She wants to contribute to the society and not just stay at home managing the household alone. This is clearly portrayed in the extract taken from the novel as stated below. 
Tang nama penyadi, enti tak diasuh apai iya badu sekula naka Pom Lima lalu belaki. Ulih ga idup baka manuk keranjai pagi empa pagi, keranjai lemai empa lemai. Ngira diri empu aja nganti ke mati. Beterenjui ai mata ia ngemasahka panggal ngenang pemerinsa diri.

Translation:

But what will happen if her father asked her to stop schooling until form five only and then get married. She can still live from hand to mouth and only thinks of her own life until the day she dies. Tears was flowing down her cheeks and wetting the pillow as she thinks of poverty in her life.

(Semaya Jawai, page 3)

Aretta's main obstacle in life is objection from her father, Janting to continue schooling and getting a tertiary education. Janting is portrayed as a villainous character who does not only restrict her daughter to get an education, he is also violent and does not openly show love and affection to his family. Despite all hurdles and challenges, Aretta is determined to be self-actualized as a person as quoted from the novel below:

Enti anak Iban deka maju sereta mansang baka bansa bukai, penemu, runding enggau ulah enda tau enda diubah, ku ati Aretta.

Translation:

If Iban youths want to be advanced and move forward just like other races, knowledge, mindset, and attitude must change, Aretta thought to herself. (Semaya Jawai, page 3)

Aretta moves from the first tier of the Maslow Hierarchy of Needs to the second one and so forth as she has a strong will to be successful. At the same time she also receives full support from her mother, teachers, friends and the longhouse folks. Towards the end of the story, her father also shows his support for his daughter to continue schooling. All this lead to her self-actualization at the end of the novel.

\section{The Physiological Needs}

In Semaya Jawai, Aretta is an ambitious Iban girl who resides with her family in a longhouse which was situated quite far in the interior part of Sarawak. The Ibans have been living together as a community in a longhouse and that gives them a unique identity. A longhouse is home to the relatives and this is a proof that their family ties are strong (Vinson, 1978). An Iban longhouse is usually far in the jungle and situated near the river as there are plenty of edible plants, fish and wild animals nearby. According to Vinson (1978), the location of the longhouse is more to survival skills for the Ibans. In Aretta's case, the journey from the longhouse to the nearest town take two hours by longboat as shown below.

Pejalai dua jam ari rumah sida ke Pasar Selangau ngelama tu jauh asai.

Tang pagi nya tak enda berasai. 
Translation:

All these while, the two hours journey from their longhouse to the Selangau town seems far. That morning they reached Selangau in no time.

(Semaya Jawai, page 18)

Nowadays, many Iban modern longhouses are made of concrete with beautiful modern interiors depending on the socio-economy of the family. Traditional Iban longhouses made from wood, just like the one Aretta and her relatives dwell in still exists until today. The wooden structure of the longhouse is indirectly implied as below:

Sekeda ari sida nya begagai kejah-kejah nujah gegar papan. Iya ke enda nakal nyabak tepantup ba tiang.

Translation:

The kids are carefree and simply running happily on the wooden floor. The crybabies cry as they knocked into the pillar.

(Semaya Jawai, page 40)

The longhouse is equally significant to Aretta, just like her school hostel. The longhouse fulfils Aretta's physiological needs as she seeks shelter there along with her family members and relatives. Twenty-five families live in Aretta's longhouse and each of the families stay in their own personal units.

Semua ruai rumah panjai dua puluh lima pintu nya udah terang magang dipanchar api elektrik ari projek MRP ti diberi YB Mauh.

Translation:

The ruai (verandah) of the twenty five units' longhouse is brightly lighted by electricity from MRP (Minor Rural Project) project funded by YB Mauh.

(Semaya Jawai, page 39)

According to Jensen (1974), the longhouse is divided into seven parts mainly bilek, sadau, ruai, tanju, dapur, padong, and tempuan. Each family lives in their own unit. It is the Iban custom for newlyweds to have their own unit and start a family. Aretta's parents have their own unit in the longhouse. Aretta has her own bedroom and she stays in the bedroom after she was dragged home from school by her father. Besides, Aretta usually runs to her uncle's unit which is nearby whenever she needs moral support as her father is fierce and hot-tempered.

“Rariiii Endunnn! Jampatt...!” Benat munyi nyawa serauh Tambung. Aretta berumban angkat ari kusyen, lalu pansut ke ruai. Ia belanda-landa ke setak ruai nuju ruai Apai Mawat lalu tama ke bilik.

Translation:

"Run for your life, Endun! Hurry up!" Tambung's voice was hoarse as she screamed in terror. Aretta quickly got up from the sofa and ran out to the 
ruai (verandah). She ran to Apai Mawat's ruai and entered the living room.

(Semaya Jawai, page 91)

In this novel, it is clearly stated that there is a living room, kitchen and bedroom in each of the unit in the longhouse. Here, Aretta's physiological needs is catered for as she lives in a comfortable house with her family. The condition of the longhouse is pictured in the citation below:

Iya angkat ari katil lalu pansut ari bilik peninduk, mansang semak apai ia baru. Indai ia baru udah pansut ari bilik dapur nunga laki ia.

Translation:

She got up from her bed and came out from her bedroom, walking towards her father. Her mother just came out from the kitchen and sat in front of her husband.

(Semaya Jawai, page 4)

The longhouse is a symbol of strength for Aretta and at the same time it indicates that whenever Aretta is forced to return to the longhouse, her motivation in the quest for self-actualization has dimmed. Aretta normally returns to the longhouse to lick her wounds whenever she feels down and not motivated to continue schooling. However, if she is strongly motivated to study, she will choose to stay at her school hostel and revise her notes as shown below:

Ujung minggu nya, Aretta enda pulai ke rumah taja semampai enda betah ngenang indai enggau menyadi iya Linni. Iya ngambi peluang dua hari nya ngulang pelajar iya. Iya enda mindah kin kia.

Translation:

During the weekend, Aretta did not go home although she missed her mother and sister, Linnie dearly. She took the opportunity to revise her studies on Saturday and Sunday. She did not go out and just stay at the school hostel.

(Semaya Jawai, page 127)

At the beginning of the story, Aretta was stranded at home at the beginning of school semester as her father, Janting prohibits her from continuing her studies in form five. He cites financial problem as the reason why Aretta must stop schooling and stay at the longhouse to help her mother with household chores.

"Endun! Nuan anang beguai pulai ke sekula minggu tu."

Translation:

"Endun! No need for you to return to school this week."

(Semaya Jawai, page 1) 
Nevertheless, Aretta managed to sneak out to Selangau town along with her mother, Tambung and they both went to Aretta's school in Sibu. Aretta managed to register herself at the school. Unfortunately, her father found out and forced her to return to the longhouse. Her teachers have to travel to the longhouse to persuade him to allow Aretta to return to school.

\begin{abstract}
"Chigu! Ni Jawai?” Pengajar Jim Bantan ngetu ngajar lalu ngansak ngagai Janting ti benung sengah-sengah bediri ba mua pintu bilik kelas nya. Aretta nensamka mua, nyeling mimit. Kesal ati iya. Baka ke nemu utai ke deka nyadi, gamal mua iya puchat. "Bisi ia ditu aya. Nama deh?" "Aku deka mai anak aku pulai."
\end{abstract}

\title{
Translation:
}

"Teacher! Where is Jawai?" Mr Jim Bantan stopped teaching and walked towards the door where Janting was trying to catch his breath. Aretta made a face and glanced at the door. She was nervous. Her face was pale as she could predict what would happen next. "She is here, uncle. How can I help you?" "I want to bring my daughter home."

(Semaya Jawai, page 30)

In another incident, Aretta returned home for good as she thought that her teacher, Mr Jim Bantan has betrayed her. She accused him of reporting her father, Janting to the police. She only returns to her boarding school when she feels loved and appreciated. She returns to school when Mr Jim picked her up and made arrangement for her to see Janting in police lock-up. This is shown in the extract below.

Aretta pansut ke tanju lalu nyenguk ke pendai. Udah sedia deka bekejang perau beinjin 30 kk Tuai Rumah Sawing ba jelatung. Pengajar Jim agi megai tali perau malik ke atas. Tambung enggau anak iya beguai-guai nurun ari rumah nuju ke jelatung. Tampak gamal mua Pengajar Jim. Empai tentu manah тиa Aretta maya ke besatup perening enggau Pengajar ia nya. Agi nyima.

\section{Translation:}

Aretta came out to the roofless platform in front of the longhouse and peeked at the riverbank. The headman, Tuai Rumah Sawing was preparing to leave in a longboat equipped with a 30 horse power outboard engine at the wharf. Mr Jim was still holding the rope of the boat and he looked directly at the longhouse. Tambung and her daughter hurriedly walked towards the wharf. Mr Jim looked pleased but Aretta was still not happy with him. She was still suspicious of him.

(Semaya Jawai, page 122)

Here, the boarding school is also a symbol of motivation in order for Aretta to fulfil her dream to get a tertiary education. Aretta's physiological needs for shelter is quite evident in her quest for self-actualization. Without the shelter in the school hostel which is also one of the psychological aspect for her motivation needs, Aretta has to forget 
schooling and just stay at home like her drop-out peers. When Aretta was pulled out of the school by her father and taken home to the longhouse, her motivation level plunged down to the extent that she also refused food.

"Endang enda tentu pansut ari pangking sekumbang ke pulai ari sekula suba. Makai meh enggai,” ku Tambung nyaut... Kada enda sakit anembiak nya, ku ati Pengajar Jim.

Translation:

"Since coming home from school the other day, she really locked herself up in her bedroom. She also refused her meals," answered Tambung... Mr Jim has a notion in his head that the child might be unwell.

(Semaya Jawai, page 36)

Besides having a shelter on her head that acts as a motivational tool to inspire her to move forward, Aretta is also blessed with parents who provide other basic needs such as food for her. Aretta's mother is a responsible housewife who prepares food daily for her family. At the beginning of the story, Aretta was having breakfast with her mother, Tambung. They were enjoying a hearty meal that consists of rice and a tasty dish of catfish mixed with cucumber shoots.

Aretta nudukka diri ba kerusi nunga segelas kupi ti udah disalin indai iya dia. Iya neguk mimit ai kupi ti agi berasap ba changkir nya. Daun rampu gulai ikan keli udah mansau lalu dituang Tambung ngagai bisin mit jebung di atas mija nya... "Anang tusah ati Endun," ku Tambung sambil ngauk kerat ikan keli ngagai pinggai asi iya.

\section{Translation:}

Aretta sat on a chair and she stared at the cup of coffee served by her mother. She sipped the steaming hot coffee slowly. A dish of catfish mixed with cucumber shoots is ready and Tambung served it in a plastic bowl. ... "Don't worry, Endun," said Tambung while she scooped a piece of catfish onto her plate of rice.

(Semaya Jawai, page 7)

Such food is clearly coming from the family's farm as the Ibans are known to grow their own food such as rice, tuber based plants, vegetables and maize. According to Vinson (1978), a plentiful harvest will uphold their image and prestige in the Iban community. This is also emphasized by Chameline (2013), that paddy planting is not just for food but also for status and good image. Sometimes, Iban men go hunting and bringing home a killed deer or a wild boar is a symbol of bravery and masculinity. A killed animal is a prized trophy for Iban men. In the novel, men bring home food and vegetables from the market for their family.

"Baka nya meh ulah iya enti datai nyabung. Enda mandi. Makai meh enda. Bisi utai dibai iya peda nuan, Endun?" "Nama utai dibai! Lalu 
empai tama ke bilik iya nya. Baka ni aku deka berandau enggau apai, ngasuh iya nganjung aku pulai ke sekula pagi ila?” Aretta muchau baru.

Translation:

That's how he behaves after coming home from cock fighting games. He doesn't take his bath. He also doesn't take his dinner. Did he bring food home, Aretta?" "He doesn't bring home anything. He haven't even enter the house. How am I supposed to talk to him, as I want him to send me back to school tomorrow?" Aretta grumbles.

(Semaya Jawai, page 10)

Besides, Aretta's need for food is fulfilled because her parents also reared livestock besides planting paddy. The Ibans have food in abundance as they are skilled in setting up traps, fishing and collecting edible ferns and plants from the jungle. Aretta's mother is shown to rear livestock such as pigs and chickens in this extract:

Kukuk manuk nyau beteranjak bertimbal-timbal. Ruik anak uting di ujung bilik pen nyau beterengik nganti seku gulai repu mulung ke dituang ngagai apan. Udah tembu makai, Tambung angkat ngenyit beguai-guai nuju langkau padi ba ujung tanju, ngambi seku lalu dilumai iya enggau tedai asi ti dibai iya ari dapur tadi. Iya nurun ke tengah laman beberika jelu tupi iya makai.

Translation:

The cocks were crowing. The hungry piglets were noisy waiting to be fed. After having her breakfast, Tambung got up suddenly and rushed towards the little hut where they store paddy. She scooped some rice husks and mixed it with leftover rice from the kitchen. She went down to the house compound to feed her livestock.

(Semaya Jawai, page 8)

Meanwhile, in the modern time having a plate of noodles in the coffee shop while running errands in nearby town is also for status and image. When the mother and daughter were on a secret mission to Selangau town in order to pawn a gold bangle, Tambung also rewarded Aretta with a plate of kampua mee and a can of carbonated drink. Having kampua mee in coffee shops is considered a treat among the Iban as they lived quite far from town and the journey itself is long and tiring.

Aretta minta mee kam pua enggau coca-cola. Tambung nitih aja pilih anak iya.

Translation:

Aretta ordered kam pua mee and a can of carbonated drink from the waitress. Tambung was also making the same order.

(Semaya Jawai, page 22) 
To conclude, Aretta physiological needs in term of shelter is met in the novel. Take note that this character depends on this need greatly in her quest for self-actualization. As mentioned earlier, being poor and living far in the interior part of Sarawak, has made the school hostel a significant need for Aretta. Without a place to stay in the school hostel, Aretta would not be able to continue schooling and achieve her ambition. At the same time, her longhouse is also quite important for her but in this context it only serves merely as a shelter, and not a sign of achievement. This is because whenever Aretta was forced to return home, it means that she has failed in her quest for self-actualization.

Moreover, her physiological needs in term of food does not affect her level of motivation to continue her studies. Food is always in abundance for this Iban family as they are skilled to find jungle produce for their daily consumption. Thus, Aretta is motivated to fulfill her safety needs after her physiological needs are met.

\section{The Safety Needs}

From the examples stated above, it is clear that Aretta's physiological needs are met by her parents. Aretta dwells in a nice and decent longhouse and at the same time, food is always plentiful at home. The Maslow's Hierarchy of Needs suggests that once the satisfaction of the physiological needs are met, an individual will be motivated to progress to the next level that is the safety needs. This is true in Aretta's situation as safety while using longboats from her longhouse to the Selangau town is very important. Aretta's cousin named Mawat and her mother ensured that they arrived safely at the nearest clinic when Aretta was beaten by her father. Mawat was extra careful while handling the longboat as the sun has set and it was getting darker.

Berjimat-jimat tudah Mawat ngemudika perau sida tiga enggaika telantakka batang anyut. Ai sungai agi ulih peda laban senawah langit. Naka ulih Indai Mawat nengau ai beratika kayu anyut enggau tuga.

\section{Translation:}

Mawat was very careful while controlling the longboat to ensure that their longboat will not knock into floating logs in the river. The water can still be seen clearly, thanks to the faint moonlight from the sky. Indai Mawat did her best ensuring that no floating tree stumps and logs are blocking their way.

(Semaya Jawai, page 92)

Next, a harmonious family is also important as it will make the family members feel safe and loved. Janting is pictured as a hot-tempered man and even his wife is scared of him. Both mother and daughter always run to the village chief's unit in the longhouse whenever Janting tried to harm them. Such incidents happened twice in the novel.

"Ni iya deh! Anang bula-bula, dek. Sepi asai...!" Semetap tapa jari iya terengkah ba kuyu Tambung. Panjai telian terais pedis Tambung ngelarika diri di sebelah bilik. Janting ngagai, deka nampar bini iya baru, tang Tambung jampat-jampat engkechit nuju mua pintu. Berumban iya mansutka diri ke ruai lalu belanda-landa ngagai bilik Apai Mawat. Translation: 
"Where is it? Don't lie to me. Serve you right!" He slapped Tambung hard on her cheeks. Tambung screamed hysterically in pain and tried to free herself from Janting. Janting chased after her, in his attempt to slap her again, but Tambung managed to flee to the verandah through the main door. Tambung ran as fast as her legs could carry her to Apai Mawat's unit in the longhouse.

(Semaya Jawai, pages 28-29)

The first incident happened after Janting found out that Tambung has pawned her gold bangle so that she could send Aretta to school. Next, he also hit both his wife and daughter as he believed rumours that Aretta was in love with her classmate in school. Janting was furious as he trusted his daughter to study hard and he has placed a high hope that she would change the family's lifestyle one day. Both tragic incidents almost caused Aretta to stop schooling. Only after Janting turned over a new leaf, Aretta feels safe and she continues schooling. In the end, she sat for the Sijil Pelajaran Malaysia examination and passed with flying colours.

At the same time, the family's financial background is also an important factor in motivating a child to study harder. Janting once asked her daughter to stop schooling as he was reluctant to pay for her expenditure and school fees.

"Kira ke enda alah pelanja aku meh nuan, Endun. Nyamai jaku nya," ku Janting muntangka penemu iya laban ke enggai agi berunding, enggai kiruh betalatka penemu pasal sekula agi.

Translation:

"Well, I guess I cannot afford to pay for your school fees anymore, Endun. I think that is the best explanation," said Janting as he tried to avoid talking about the topic of sending Aretta back to school.

(Semaya Jawai, page 5)

Aretta was an excellent student, so her mother took the initiative to pawn her gold bangle for money, so that she could send her daughter to school. Cash is always tight for the farmer family, so pawning any jewellery that they own is the best solution to get fast money.

\section{“Enti pia gelang emas aku tu ga gadai kena Endun dulu,” ku Tambung.}

Translation:

"If that is the case, just pawn my gold bangle so that Endun can pay her school fees," said Tambung.

(Semaya Jawai, page 5)

When Janting was put behind bars for child abuse, Aretta's hope of continuing her studies was smashed as there was no financial support from her family. Janting was the sole bread winner, and when he is jailed Aretta has to stop schooling. Aretta's motivation level was really down this time as she has given up hope to achieve self-actualization. 
"Eehhh...! Pas manah pen aku nadai meh guna. Sapa orang melanja aku enti apai masuk jil? Muni diri ngapa meda orang gaga masuk sekula tinggi ila!” ku Aretta nyelepak baru.

Translation:

It is useless even if I passed the examination with flying colours. Who will support me financially if my father is put behind bars? I will just envy other people going to universities to further their studies!" Aretta chipped in.

(Semaya Jawai, page 121)

However, Aretta's motivation to study is back on track after getting support and help from her form teacher, Mr Jim Bantan. Mr Jim supports Aretta morally as he realized that Aretta is very bright and she is a high achievement student. Mr Jim introduced Aretta and her mother to a state representative in the parliament in their area who later gave Aretta financial assistance to further her studies in Universiti Malaysia Sarawak (UNIMAS). The words of encouragement from the minister is an important factor that triggered Aretta nearer to her dreams to be self-actualized.

“... Nyadi..., kena nuan ngepunka diri masuk, aku meri bantu enggau mata duit dua ribu ringgit, tu enda ibuh dibayar nuan. Nya kena aku mantaika pengaga ati aku meda anak kitai Iban ulih ngagai sekula tinggi. ... Baka bayar bukai aku mega ulih meri pinjau ngagai nuan nganti Pengajar Jim ke ngaduka scholarship pelajar nuan. Pasal scholarship nuan tu, anang irau, nya nadai penanggul, asal meh pemutus peresa nuan manah belama ila..."

Translation:

"So, for your initial financial support to the university, I will give you two thousand ringgit. You don't have to repay this sum of money. This is a token of appreciation from me because I am happy that an Iban child like you is making your way into the university. For other expenses, I can lend you some money while waiting for Mr Jim to make arrangement regarding your scholarship. Do not worry about your scholarship, there is no problem provided your examination results are always excellent..."

(Semaya Jawai, page 151)

Finally, Janting is a changed new man and he granted permission for his daughter to continue schooling and finally going to the university. Janting was put behind bars for child abuse charges. This incident has led Aretta to achieve her need for self esteem and she passed her Sijil Pelajaran Malaysia examination with flying colours as her father is not in the way to block her success in her studies.

“Minta ampun ... anak ... Endun ...” Raguk basah munyi nyawa Janting sikuk-sikuk. Semadi-madi iya ke ulih ngenataika jaku seleka dua," ... Indai Endun ... chigu ... Aku amat salah Endun ... Anang kiruh nyamin aku kita ... Awakka penau perintah ngukum aku ngipakka penyalah aku 
... Chigu...! Nulung aku ngemataka Endun ba sekula... aku arapka nuan chigu..."

Translation:

"Please forgive me ... my girl... Endun..." Janting's voice was hoarse as he sobbed uncontrollably. He had difficulty finding his words. "Indai Endun... teacher... I have wronged Endun... do not bail me. Let the authority punished me for what I have done... Teacher! Please keep an eye on Endun on my behalf. I am depending on you, teacher..."

(Semaya Jawai, 124)

When a child feels safe from abuse, she will have a motivation to study and do better in life. This is indeed true in Aretta's case as she can finally study at ease when he father, Janting stopped interfering in her schooling matter. Aretta's motivation to seek self-actualization also greatly depend on safety needs in term of having a harmonious family and solid financial background. For Aretta, using a risky transportation, in this case a longboat does not affect her motivation level to seek self-actualization as travelling via river is part and parcel of her life as a rural Iban kid.

However, living in the longhouse with a father who is not only financially unstable, is a nightmare for Aretta as he is also violent and hot-tempered. Although her father is pictured fierce and her safety needs is not catered for when she is at home, Aretta seeks support and protection from her other relatives who lives in the same longhouse.

Last but not least, financial problems seems to hinder Aretta from achieving selfactualization. As Aretta hails from a poor family background, money problem is a major obstacles that can affect her motivation level. Aretta is lucky to have a supportive mother and school teachers who help her to fulfill her safety needs in term of financial stability. As a result, she is motivated to pursue her studies and is on her way to self-actualization.

\section{The Belongingness and Love Needs}

Aretta was brought up in a happy family and she was loved by her parents dearly. However, conflict in the family started when Janting requested that Aretta stop schooling and stay in the longhouse, helping her mother with household chores. Aretta was torn between love for her family and her quest to be self-actualized. She is also the main reason why her parents fought as they could not compromise in Aretta's education matters. Despite all that, a mother's love rise above all and Tambung was willing to go against all odds to find funds for Aretta to continue her studies. She secretly pawned her gold bangle to an old friend of hers for four hundred ringgit so that she could send Aretta to school.

\footnotetext{
"Gelang emas aku tu meh gadai ba Tauke Ah Chai di Pasar Selangau pagila." "Enda nganu nuan apai?" "Enda nemu meh." "Enda ibuh meh indai. Aku enggai ngenusah nuan miga-iga. Kasih ga nuan dianu apai ila."
}

Translation:

"I will just pawn my gold bangle to Tauke Ah Chai in Selangau town tomorrow." "Will father be angry at you?" "I don't know." "It is okay, 
mother. I don't want to trouble you for no reason. I pity you as you will be scolded by him later."

(Semaya Jawai, page 7-8)

Besides, a motherly love for her daughter is also portrayed when Tambung defended Aretta who was badly beaten by Janting as she was accused of flirting with a boy from her class. Tambung was willing to do anything even if that means hurting herself as she was really keen to see Aretta happy. Aretta's happiness is continuing her studies to the university. Her mother's love and supportive way is surely a motivation for her.

Tambung nguji baru deka ngerampas batang penyapu nya. Ulih pegai iya ujung batang penyapu nya, tang jampat dikesaika Janting. Tambung tepelanting ke geladak. Mimit agi tepantup ba tiang tengah pala iya.

Translation:

Tambung tried to snatch the broom again. She managed to hold one end of the broom but was rudely pushed aside by Janting. Tambung fell unto the floor. Her head almost hit the main pillar in the house.

(Semaya Jawai, page 90)

Moreover, even though Janting is portrayed as a fierce and hot-tempered person, deep in his heart, he loved Aretta dearly. He trusted Aretta and even willing to fork out some money to have a thanksgiving ceremony for Aretta to return to school. At first, Janting was furious as his wife didn't respect him as a breadwinner and quietly send Aretta to school without his acknowledgement. However, he changed his mind after a group of Aretta's teachers who came all the way from Selangau town manage to open his eyes about the importance of education. A traditional Iban man like Janting does not show his affection directly, but his approval to send Aretta to school is surely one gesture of love.

"Sediaka magang barang ke deka dibai nuan, Endun. Tumu dani pagila." Alus bendar jaku Janting nangkan anak iya. Tambung nyaup Endun ngelipat pakayan anak iya. Udah dilipat, pakayannya tadi disimpan iya dalam beg. Betambah ransing ati Aretta deka nurun ke sekula meda pemanah ulah apai enggau indai iya.

Translation:

"Get ready all the things that you need, Endun. Don't forget to wake up early tomorrow." Janting spoke softly to remind his daughter that they will send her back to school. Tambung helped Endun to fold her clothes neatly and put them into the luggage bag. Aretta is excited and motivated to study as her parents are giving their full support to her.

(Semaya Jawai, page 69)

At the same time, Aretta is also very lucky as she was the apple of her teachers' eyes in school especially for Mr Jim, who is also her form teacher. Mr Jim is a caring teacher and he always ensures that Aretta's welfare is well taken care of. He takes good care of Aretta as she is a bright student and it is a great loss if she stopped schooling. Here 
is an extract from the novel that shows that Mr Jim cares so much for Aretta. He was stressed when Aretta was still absent from school after her medical leave was over.

"Peremisi sakit Aretta abis Hari Empat. Hari Lima tu iya patut datai ke sekula. Nama ia enda datai ga hari tu?" Pengajar Jim nanya anembiak iya. ... "I'm talking to you, Julia! You hear me?" Pengajar Jim merakka nyawa ia.

Translation:

Aretta's medical leave ends on Thursday. She ought to go to school on Friday. Why is she still absent today?" Mr Jim asked his students. "I'm talking to you, Julia! You hear me?" Mr Jim raised his voice.

(Semaya Jawai, page 112)

Julia is Aretta's best friend. Love and support from her friend has always motivate Aretta to move forward. They also spend time studying together. Julia loves and cares for Aretta's welfare. For instance, she hurriedly fetch her friend, Aretta from Mr Jim's car when they returned to the hostel from the hospital.

Julia beguai-guai nurun ngambi pangan iya nya ari kereta Pengajar Jim.

Translation:

Julia hurriedly went down the stairs and fetched her friend from Mr Jim's car.

(Semaya Jawai, page 103)

A boy from her class named Roy also loves Aretta dearly. Roy tried to confess his feelings but Aretta has taken a wise move by saying that they are just friends. Roy's feelings towards Aretta is portrayed in this extract:

Roy berunding enda lama sebedau nulis siti ayat, "aku rindu ka nuan, Ta. Love you."

Translation:

Roy thought for a while before writing a sentence, "I love you, Ta. Love you."

(Semaya Jawai, page 77)

Here, Roy plays an important role in motivating Aretta in her quest for selfactualization. He is a bright boy and they together with Julia always study together and help each other.

It is indeed true that the sense of belongingness and love from family, teachers and schoolmates has a deep impact on Aretta's motivation to study. Aretta was almost achieving the forth tier in Maslow's Hierarchy of Needs when a schoolmate named Umang who is jealous of her friendship to Roy, bad-mouthed her and told untrue stories to the villagers. 
"Entah! Ni nemu. Tusah dikarapka Endun nuan nya, ibuk. Semampai ke Sibu begulai enggau orang lelaki. Aku kala meh meda ia dating enggau pangan iya ba kelas sida," saut Umang ngambi peluang nusi berita pasal Aretta. Nyau asai ke dipandam dada Tambung ninga berita nya. Janting ninga mimit puting randau Umang enggau bini iya.

Translation:

"Who knows? Don't believe everything your daughter told you, auntie. She always sneaks off to Sibu with men. I have seen her flirt with a boy from her class," Umang answered, taking the opportunity to bad-mouth Aretta. Tambung was heart-broken when she heard the news. Janting eavesdropped the conversation between Umang and his wife.

(Semaya Jawai, page 83)

Consequently, Aretta was badly beaten by Janting who was then jailed for abusing his daughter physically. Aretta was unhappy with Mr Jim as she thought that the latter has reported her father to the authority, causing Janting to be placed behind bars. Even Roy whose love proposal was rejected by Aretta tried to tarnish her name by spreading rumours that Aretta is the person behind Mr Jim's marital problems.

"Sabar, Ta. Chemburu Roy ke bendar nya. Sida bukai nampung ngapa, alah kemulaka iya." "Bah! Nama utai ditusi Roy deh, Ju?" "Nya meh. Ia nusi ba kelas, bini Pengajar Jim rari ketegal nuan. Sida bukai arap ngapa, enda nemu cherita ke amat. Dini sida bangat nemu hal pengajar kitai nya."

Translation:

"Be patient, Ta. Actually Roy is jealous. The rest believed his lies and spread the news." "What did Roy tell them, Ju?" "He told our classmates that Pengajar Jim's wife left home because of you. They simply believed everything he said, although they do not know the actual story. They cannot be so well-versed about our teacher's personal life."

(Semaya Jawai, page 127)

Here, we can conclude that the belongingness and love needs is very important for a student like Aretta. The lack of love and acceptance from people around her can cause her motivation level to plunge down and goes back to basic that is just to fulfil the physiological needs only. Aretta is seen returning to the longhouse whenever her spirit is down.

"Sekula nuan hari tu, Ta?" "Enda. Pulai ke rumah." "Lama?" "Enda nemu meh! Enda pulai kitu agi, kini."

Translation:

"Are you going to school today, Ta?" "No. I am going home." "For how long?" "I don't know. Maybe for good."

(Semaya Jawai, page 110) 
In a nutshell, when people around her including her parents, teachers, friends and society support her dream, Aretta feels loved and she is able to progress to the next tier in Maslow's Hierarchy of Needs. Aretta's motivation to strive for self-actualization is also sparked by love and support from her parents, teachers, friends, and society. Aretta is motivated to excel in her studies when people around her show their love and affection towards her.

However, Aretta also faced obstacles in achieving self-actualization as her own father, Janting does not allow her to continue schooling. Janting is portrayed fierce and violent, and he does not show love and affection towards his family openly. Despite his violent nature, Janting still has a soft spot for his daughter and this is shown later in the novel when he gives his full support to Aretta to continue her studies.

At the same time, Aretta also receives full support from her mother and teacher in her quest for self-actualization. These important figures are willing to go all out to ensure that Aretta is able to achieve her ambition. They not only support Aretta morally but also financially as well. Their effort have earned Aretta success in the public examination.

Lastly, Aretta is also surrounded by her peers in the school. Her best friends helped her to achieve self-actualization but a few bad apples have caused her trouble and obstacles. It is rivalry from a jealous schoolmate that has landed Aretta into a serious family feud with her own father. Consequently, this incident has ripped off Aretta's motivation level and she almost dropped out of school if not for her teacher's concern about her welfare. A caring and concerned teacher finally put Aretta back into track in her quest for self-actualization.

\section{The Esteem Needs}

An individual who has reached the third tier in Maslow's Hierarchy of Needs is a happy individual. A happy individual will be motivated to reach a higher level of motivation in life that is the esteem needs and lastly the need for self-actualization. Aretta has succeeded in overcoming the obstacles in her life and finally she is at the fourth tier that is the esteem needs.

Aretta's esteem needs is also fueled by her mother's love at the beginning of the story. She is motivated to continue schooling and vow to do her best as she receives full support from her mother to register herself at the school despite her father's objection.

Aretta is a clever student and she passed her Sijil Pelajaran Malaysia (SPM) examination with flying colours. Such examination results is expected as she also did quite well in the mock SPM examination in school.

Aretta enda rawan ati nganti pemutus peresa Percubaan SPM II. Bisi kereja bisi ga upah. Ia bulih 8A. BM, BI, BIO, Mate semua Al, SEJ, MT, Fizik, Kimia, semua A.

Translation:

Aretta is not worried about her mock SPM examination results. You reap what you sow. She scored straight As. She scored a distinction in Malay Language, English, Biology, and Modern Mathematics. She also scores an A in other subjects like History, Additional Mathematics, Physics and Chemistry. 
Such excellent examination results has earned Aretta a place in the local university. This is quite an achievement for a poor student who hailed from the interior part of Sarawak like Aretta. Aretta is getting nearer to achieving self-actualization as she makes preparation to go to the university.

At the same time, Aretta also need to set a good example for her younger siblings to follow in her footsteps. She wants them to study hard. It is mentioned in the story that the longhouse folks looked up to Aretta as she is out-spoken and dare to voice out her opinion regarding education. Moral support from the society especially her own people in the longhouse has made Aretta a confident person. Thus, she is even keener to be selfactualized.

\title{
The Need for Self-Actualization
}

Aretta is not just an ordinary Iban girl who would just get married, have kids, and live a traditional life at the longhouse; planting paddy, looking for jungle produce, and rearing livestock. She is a girl with a strong will and she has overcomes all odds to be out of poverty and be successful in her life. She believes in herself and she is highly motivated that she will be successful if she wanted to.

\author{
“Ingat aku, Sir. Juluk ati aku..., anak Iban, Dayak..., bansa Malaysia \\ mesti deka setanding enggau bansa bukai di dunya tu. \\ Translation: \\ "I remember that, Sir. My dream is to see an Iban, a Dayak and a \\ Malaysian to be at par with other races in this world.
}

(Semaya Jawai, page 159)

She yearns to change her family's life for the better and she even dream to rub shoulders with important figures in Sarawak administration line to improve the standard of living among the Ibans in the interior part of Sarawak.

"Eh? Enggai aku napi pengidup baka nya. Baka ni? Aku deka ngupas jalai ka anak indu bansa Iban ba menua pesisir. Enggai ngurung diri ngena penemu ti pabu nadai tuju pengidup bakanya... Sarawak ulih! Anak Iban ulih! Anak indu pen ulih?"

Translation:

I don't want to live such a life. How am I going to lead the way to success among Iban girls from the interior part of Sarawak? I don't want to confine myself believing such old fashioned notion and living a life that leads nowhere. Sarawak can do it! Iban child can do it! Even an Iban girl can also do it!"

(Semaya Jawai, page 9)

In conclusion, Aretta will not be self-actualized if her psychological needs, safety needs, love needs, and esteem needs are not met. Aretta's motivation goes up and down as she paths her way to self-actualization. The degree of fixity in Maslow's Hierarchy of Needs is clearly emphasized in Aretta's case when her spirit is down as her own father 
does not support her to continue studying in form five and sit for Sijil Pelajaran Malaysia examination.

\section{Conclusion}

To sum up, the author of this motivational novel wants to inspire Iban teenagers out there to achieve self-actualization in their life. He chose a girl as the main character to rely his message about school dropouts due to poverty and lack of support from people around them. Aretta Jawai in this novel is a symbol of Iban student who is almost deprived of education just because her family is poor and cannot afford to fund her studies. Choosing a girl as the main character in this novel is not something new in Iban literature. In the Iban heroic ensera, women are seldom portrayed as heroic figures, although they often incite men to deeds of bravery (Clifford, 2001). However, in the comic stories, the situation is often reversed and women always outsmart men.

Being an educator and teaching in a rural schools are reasons why the author is concerned about school dropouts especially among the Iban students. Many Iban teenagers be it boys or girls from the interior parts of Sarawak are dropping out from school each year due to poverty as cited from this extract:

"Enda tetilap Aretta beratika bala anak indu ti serambau enggau iya ba jelatung bepegaika sengayuh sedia deka nurun bejalai. "Deka kini sida nya indai?" Aretta nelai indai iya. "Ke umai pelaba aku. Begiga ke lauk, kini?" "Endang enda sekula sida nya?" "Enda meh nya. Sekeda udah badu? Entah, enda nemu. Kapa nuan nya deh?” Aretta enda nyaut."

Translation:

Aretta was observing a group of teenage girls who were her peers standing at the wharf, each holding a paddle in their hands. They were getting ready to go somewhere. "Where are they going, mother?" Aretta whispered into her mother's ear. "Maybe they are going to the farm. Looking for edible plants or catching fish for food, maybe." "So they do not go to school anymore?" "I guess so. Some are dropouts. I also do not know for sure. Why do you ask?" Aretta did not answer.

(Semaya Jawai, page 17)

Many Iban parents from the rural areas in Sarawak do not fully support their children to get a decent education, just like Aretta's case in this novel. For poor families, sending a child to school means they have to fork out extra money to pay for fees and other expenditure. In addition, when a child is send to school, the family also loses extra manpower that can be used in the farm or doing household chores.

Moreover, most people only think of fulfilling physiological needs, safety needs and love needs. For them, these needs are fairly enough for them to find a living. Here, Aretta represents a remarkable young Iban teenager who does not confine herself within the traditional Iban life that requires them to plant paddy and collect food from the jungle. She is a figure of the new generation of Iban teenagers who seek for selfactualization and contribute to the society. The author of the novel has indeed successful 
Borneo Journal of Social Sciences \& Humanities DOI: https://doi.org/10.35370/bjssh.2020.2.2-01 e-ISSN: 2682-8235

(C) 2018, UCTS Publisher.

Submitted on: 07 July $2020 \quad$ Accepted on: 25 September $2020 \quad$ Published on: 31 December 2020

in relying his message that Iban students must overcome obstacles and challenges in their life as a student until they are self-actualized as a person.

\section{References}

Akbar Yunadi., Singgih Daru Kuncara., \& Nita Maya Valiantien. (2020). Sophie's needs in Rooftoppers novel by using Maslow's theory of hierarchy of human needs. Jurnal Bahasa, Sastra, Seni, dan Budaya, 4(1), 130-144.

Benedict Sandin. (1977). Gawai burong the chants and celebrations of the Iban bird festival. Pulau Pinang, Penerbit Universiti Sains Malaysia.

Birai Dap. (1949). Two Dayak chants. Sarawak Museum Journal, 5(1), 73-76.

Chemaline Osup. (2006). Leka main: puisi rakyat Iban - satu analisis tentang bentuk dan puisi. Doctoral Thesis, Universiti Sains Malaysia.

Chintya Bayu Lestari., Ninuk Lustyantie., \& Siti Gomo Attas. (2018). Self-actualization of the main character Hujan novel by Tere Liye: a review of psychology Abraham Maslow. BAHTERA: Jurnal Pendidikan Bahasa dan Sastra, 17(1), 74-89.

Clifford Sather. (2001). Apai Alui becomes a shaman and other Iban comic tales. Kuching, Universiti Malaysia Sarawak.

Dedy Ari Asfar. (2004). Sastera lisan Iban Sungai Rimbas Sarawak: perspektif etnopuitika. Master Thesis, Institut Alam dan Tamadun Melayu, Universiti Kebangsaan Malaysia.

Freeman, D. (1992). The Iban of Borneo. Kuala Lumpur, S. Abdul Majeed and Co.

Hamzah Hamdani (pngr). (1988). Wajah sastera Sarawak. Kuala Lumpur, Dewan Bahasa dan Pustaka.

Harry Usup Umbar. (1999). Semaya Jawai (Janji Jawai). Kuching, See Hua Daily News Bhd.

Henry Gana Ngadi. (1998). Iban rites of passage and some related ritual acts: a description of forms and functions. Kuching, Dewan Bahasa dan Pustaka.

Howell, W. (1911). A Sea Dayak dirge. Sarawak Museum Journal, 1(1), 5-73.

Imam Ghozali. (2020). The fulfillment of hierarchy of needs of Elinor in the "Sense and Sensibility" novel by Jane Austen: a study of humanism psychology of Abraham Maslow. Pancaran Pendidikan, 9(1), 1-8.

Jamilah Hj Ahmad. \& Jonathan Singki. (1989). Cerita rakyat Iban. Kuala Lumpur, Dewan Bahasa dan Pustaka.

Janang Ensiring., Jantan Umbat., \& Robert Menua Saleh. (2011). Bup sereba reti jaku Iban. Kuala Lumpur, The Tun Jugah Foundation.

Jensen, E. (1974). The Iban and their religion. Oxford, The Clarendon Press.

Kamus Iban - Melayu Dewan. (2016). Ed. ke-2. Kuala Lumpur, Dewan Bahasa dan Pustaka.

Krippendorff, K. (2018). Content analysis, an introduction to its methodology $4^{\text {th }}$ Edition. California, SAGE Publication.

Kuckartz, U. (2014). Qualitative text analysis, a guide to methods, practice \& using software. London, SAGE Publication.

Maslida Yusof., Mohammed Azlan Mis., Yusmilayati Yunos., \& Mohamad Rodzi Abd. Razak. (2015). Malaysia - Indonesia: bahasa sastera dan budaya. Bangi, Penerbit UKM. Maslow, A. (1954). Motivation and personality. New York, Harper \& Brothers. 
Noriah Taslim. \& Chemaline Osup. (2013). Ensera ayor: epik rakyat Iban. Pulau Pinang, Universiti Sains Malaysia.

Nurhamizah Hashim., Eizah Mat Hussain., \& Nur Yuhanis Mohd Nasir. (2017). Unsur Psikologi Maslow Dalam Novel Terpilih. PENDETA - Journal of Malay Language Education and Literature, 8, 72-81.

Perham, J. (1885). Kliengs war-raid to the skies: a Dayak myth. Journal of the StraitsBranch of the Royal Asiatic Society, 16, 266-288.

Richards, A. J. N. (1949). The migrations of the Ibans and their poetry. Sarawak Museum Journal, 5(1), 77-87.

Rubenstein, C. (1973). Poems of indigeneous peoples of Sarawak: some of the songs and chants. Sarawak Museum Journal, 21(42), 35-280.

Vernon, M. D. (1969). Human motivation. Great Britain, Cambridge University Press. Vinson, H. Jr. (1978). The Iban of Sarawak. Illinois, Arlington Heights. 